\title{
THE USE OF INNERVATED FLAPS FOR THE CLOSURE OF ISCHIAL PRESSURE SORES
}

\author{
By S. Krupp, M.D., ${ }^{1}$ W. Kuhn, M.D., M.D.D. ${ }^{2}$ and G. A. ZaECH, M.D. ${ }^{2}$ \\ ${ }^{1}$ Chef, Service de Chirurgie Plastique et Reconstructive, Chuv, CH-IoI I Lausanne. \\ ${ }^{2}$ Schweizerisches Paraplegikerzentrum Basel, Switzerland.
}

Summary. Since I97I we have been covering pressure sores and unstable scars with transposition-rotation-muscle and musculocutaneous flaps, thereby padding the cavity resulting from excision of bone and scar tissue. The long term results compare favourably with classical random pattern skin flaps. From the beginning of I 980 we have been using the sensory innervated tensor fascia lata myodermal flap for the ischial region. This provides sensation for a formerly insensitive area in patients suffering from a spinal cord lesion below $\mathrm{L}_{3} / 4$.

Key words: Trochanteric and ischial pressure sores; Treatment by muscle flaps (musculocutaneous, and sensory innervated tensor fascia lata flaps.)

\section{Introduction}

A MAJOR factor of rehabilitation of paraplegic patients is the prevention of pressure sores, by education of the medical and nursing staff, the patient and the patient's family and by recognition and identification of high risk patients (patients with: (I) reduced mobility, (2) reduced or absent sensation, (3) loss or decrease in vasomotor control, (4) alteration in anatomy).

Nevertheless many patients develop pressure sores, which usually respond to conservative treatment:

(I) Strict immobilisation in the prone position on a pack-bed, the HessSandwich-Bed (the Swiss version of the Stryker-bed), or in special cases (age, high tetraplegics, concomitant other complications not allowing prone position) in the new 'air-fluidised' bed (Clinitron $\left.{ }^{\circledR}\right)$.

(2) Control of electrolytes; blood transfusion. (We consider an average haemoglobin of $12.5 \mathrm{~g}$ per cent in men and $\mathrm{I} .5 \mathrm{~g}$ per cent in women basic for adequate wound healing).

(3) Excision of the slough.

(4) Eradication of the infection by continuous cleansing of the sore by the help of products like sterile 0.9 per cent saline solution, solution of extractum malvae, Debrisan ${ }^{\circledR}$, and very occasionally enzymes or topical application of local antibiotics such as Fucidin ${ }^{\circledR}$.

Address for reprints: $\mathrm{Dr}$ W. Kuhn, Schweizerisches Paraplegikerzentrum, Imburgfelderhof 40, CH-4055 Basel. 
(5) Improving granulation (if this is really possible) by the help of Solcoseryl $^{\circledR}$ (local and i.m. injections), Corethium ${ }^{\circledR}$ (porcine skin) or with autologous grafts (Krupp and Zaech, I 98 I, Shand and McClemont, I979).

Plastic surgery must be considered in patients not responding to conservative treatment:

(I) Recurrent pressure sores and unstable scars.

(2) Lack of material due to the extent of the sore.

(3) Lack of adaequate padding due to anatomical changes.

(4) Preventing and treating pressure sores in certain patients by covering the ischial and/or trochanteric region with sensory innervated tensor fascia lata or other suitable musculocutaneous flaps.

\section{Methods}

Techniques, pre- and post-operative care and testing, anatomical basis.

Up to the end of the I 960 's the classical operation for closure of pressure sores and unstable scars in spinal cord injured patients, especially sores in the pelvic region, consisted in thorough excision of the lesion, resection of bony prominences following Guttmann's (I955) pseudotumour technique and coverage of the defect with a large transposition-rotation skin flap (Conway and Griffith, I956; Dansereau and Conway, I964; Campbell and Delgado, I977; Krupp, I972; Krupp et Zaech, I976).

In the rare conus lesions, Guttmann had proposed the use of a sensory transposition-rotation skin flap from an adjacent normally innervated area. However, such flaps would only provide insufficient protection due to the limited size of such 'random pattern' flap (McCraw et al., I976, I977; McCraw and Dibell, I977; McGregor and Buchan, 1980).

Improved long term results in selected patients with respect to recurrent ulcer formation were provided by padding the cavity after excision of bone and scar tissue, with muscle flaps underlying the skin flap. Such muscle flaps also permitted surgery in heavily scarred areas which could not otherwise be transformed into 'pressure stable regions'. Atrophy and degeneration of the muscle may be prevented by preserving its neurovascular bundle (Pers and Medgyesi, I973; Ger and Levine, I976; Mathes et al., I977, I979; Krupp et Zaech, I976; Vasconez and McCraw, I980).

Because no functional disability results from muscle transposition in totally paralysed patients, any muscle suitable to cover large unstable scars or pressure sores can be used. Thus in the pelvic region, the gluteus maximus muscle (or part of it), the rectus femoris muscle, the biceps and semitendinosus, the vastus lateralis muscle etc. are available. But if there is still muscle function present or if the patient can walk with crutches, the muscle to be transpositioned has to be carefully selected so as not to disturb the remaining function.

A further improvement in operating on pressure sores or scars is provided by using musculocutaneous flaps, especially when they are sensory innervated (Dibell et al., 1979; Bostwick et al., I979; Hill et al., I979; Mathes and Buchanan, I979; Nahai et al., I979; Krupp, I98I).

In patients paralysed by spinal cord injury or meningomyelocele with a sensory level below $\mathrm{L}_{3} / 4$ the sensory innervated tensor fascia lata musculocutaneous flap provides the area to be covered with the intact 
function of the lateral cutaneous nerve of the thigh. This nerve has its origin in $\mathrm{L}_{1}, \mathrm{~L}_{2}$ and $\mathrm{L}_{3}$ and can be incorporated in such a flap. As is mentioned above other but not sensory innervated musculocutaneous flaps providing padding and intact skin are the gracilis musculocutaneous flap, the rectus abdominis musculocutaneous flap and others. For the knee and the lower leg gastrocnemius and soleus musculocutaneous flaps or other flaps provide padding and skin. For the foot the dorsalis pedis flap or muscle flaps from the sole of the foot can be used to cover heel ulcers and unstable scars (Cannon et al., I977; Ger and Levine, I976; Hill et al., I979; Mathes et al., 1977; McCraw et al., I976; Nahai et al., I979; Orticochea, I972; Krupp et Zaech, I98I; Souyris et al., I980).

Long island flaps, based on intercostal vessels and nerve, may also bring sensation to the sacral area. Further advances may be brought about by using microvascular, sensory skin or musculocutaneous grafts. But the distance between the lesion and the level of sensation limits application, at least until now (Mathes et al., I977; Daniel and Williams, I973; Dibell, I974).

Before performing a sensory innervated tensor fascia lata flap (TFL) some further points must be considered:

(I) Sensory innervated TFL-flaps should be performed only in recurrent sores when conservative treatment has failed.

(2) Patients should be young enough so as to be able to 'relearn', since there is now sensation of the above knee region in the trochanteric or/and ischial region.

(3) Rehabilitation must have reached an adaequate level, and the patient must be cooperative.

(4) The neurological status has to be stable (beware of incomplete lesions still improving).

(5) The individual anatomical situation has to be carefully considered especially regarding arterial blood supply; this is essential for success. A transverse branch of the lateral femoral circumflex artery is the main supply, but one has also to pay attention to 2-3 perforating vessels in the distal third of the flap emerging from the vastus lateralis and rectus femoris muscles.

(6) Perfusion insufficiency of the distal end can be prevented by delaying the time between surgical preparation of the flap, and its final transposition. The same applies for patients with thick layers of subcutaneous tissue.

(7) In patients with a meningomyelocele the pelvis may be hypoplastic, the TFL-flap can be transposed on the inner side of the leg.

(8) The area destined for transposition has to be tested very carefully regarding all modalities of sensation (pain, touch, temperature etc.).

As we need the whole length of the flap to reach the ischial region the length of the legs has to be considered.

Pre-operative testing of motor function is essential; as well as X-ray studies for exclusion of any abnormalities (ossification, p.a.o., ${ }^{\star}$ plates from former osteosynthesis etc.).

After the operation the patient is positioned carefully on special pillows leaving the ischial and trochanteric regions totally free from pressure and

* periarticular ossification. 
tension, otherwise axonotmesis of the nerves will occur. The hip and knee is maintained in flexion of about $45^{\circ}$, and after 8-12 days the patient lies in the prone position on the pack bed for 5-6 weeks, or in special cases in a supine position on an air-fluidised bed (Clinitron ${ }^{\circledR}$ ).

\section{Results}

\section{(A) Muscle and musculocutaneous flaps}

Since I97 I at the Swiss Paraplegic Centre in Basel, we have performed 22 muscle flaps and 2 musculocutaneous flaps in 20 patients to cover unstable scars and recurrent pressure sores of the pelvic region (Table I). No major complications have occurred, neither was there any occurrence of a new sore.

\section{TABLE I}

Muscle, musculocutaneous and sensory innervated musculocutaneous flaps I 97 I $-2 / 28 /$ I 98 I

\begin{tabular}{rcr}
\hline Patients & Type of flaps & Number of flaps performed \\
\hline & Muscle flaps: 22 & I2 \\
4 & Biceps femoris & 5 \\
2 & Gluteus maximus & 2 \\
2 & Vastus lateralis femoris & 3 \\
& Gluteus maximus and vastus lateralis femoris \\
2 & Musculocutaneous flaps: 2 & 2 \\
& Gracilis & 6 \\
\hline
\end{tabular}

(B) Sensory innervated tensor fascia lata flaps

In I980, six sensory innervated TFL-flaps were performed on three patients; one male patient, 23 years old, paraplegia complete below $\mathrm{L}_{3} / 4$ since 1973 , recurrent heel ulcers, recurrent ischial bursae and ulcers. (see Figs I, 2, 3 , 4), one male patient, 24 years old, complete paraplegia below $\mathrm{L}_{3} / 4$ since 1975, recurrent heel, foot, ischial ulcers, hospitalised for these complications for 389 days and now free from any recurrence. One female patient, I9 years old with a meningomyelocele, recurrent ischial ulcers, heavily scarred trochanteric region due to correction osteotomies of the femur.

In a small selected group such advanced sensory innervated TFL-flaps can bring sensation in a formerly asensitive region, and in all cases the patients were pleased to have improved bowel control due to this 'reconstructed' sensitivity in the perianal region. 


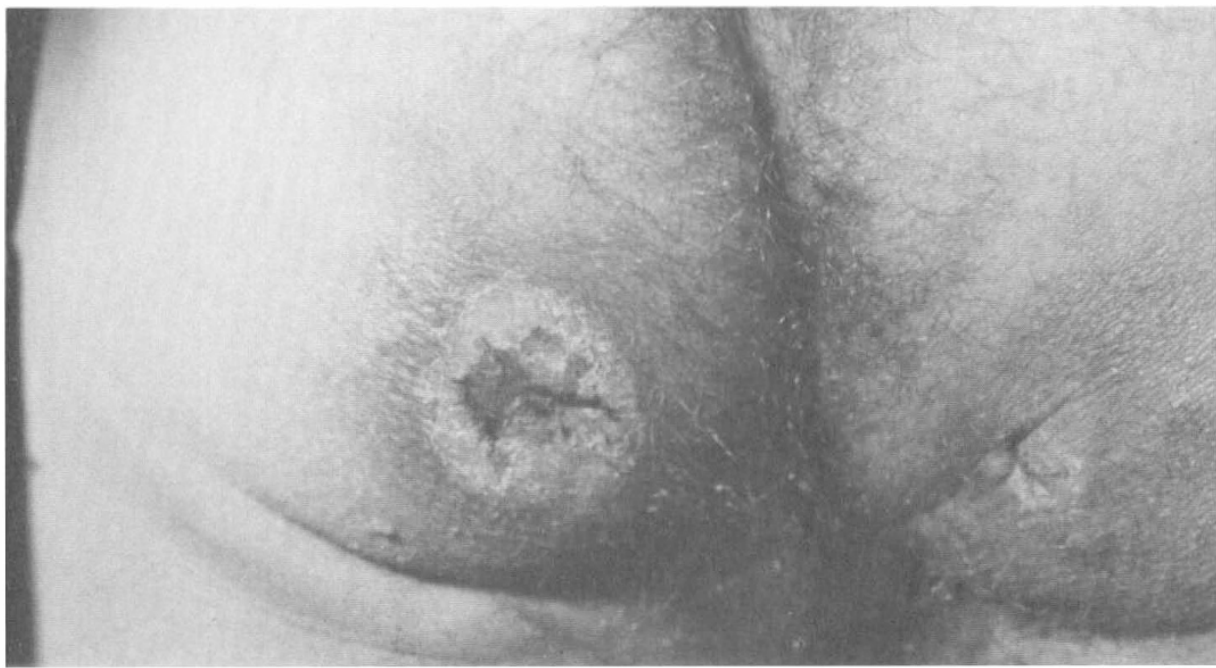

FIG. I

Recurrent ischial bursae and ulcers in a 23 year old patient, paraplegic below $\mathrm{L}_{3} / 4$ for 7 years.

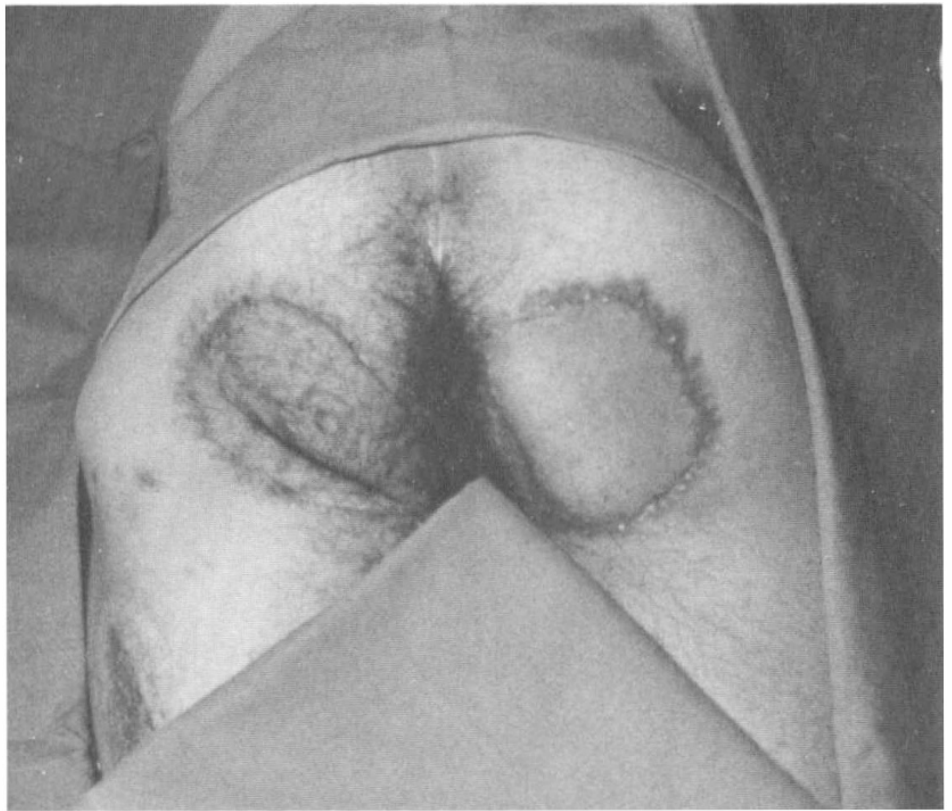

FIG. 2

On I4 April and 27 May 1980 sensory innervated tensor fascia lata flaps were transposed to the ischial region giving full aesthesia and algesia to this region. (Photo I 4 days after second intervention). 


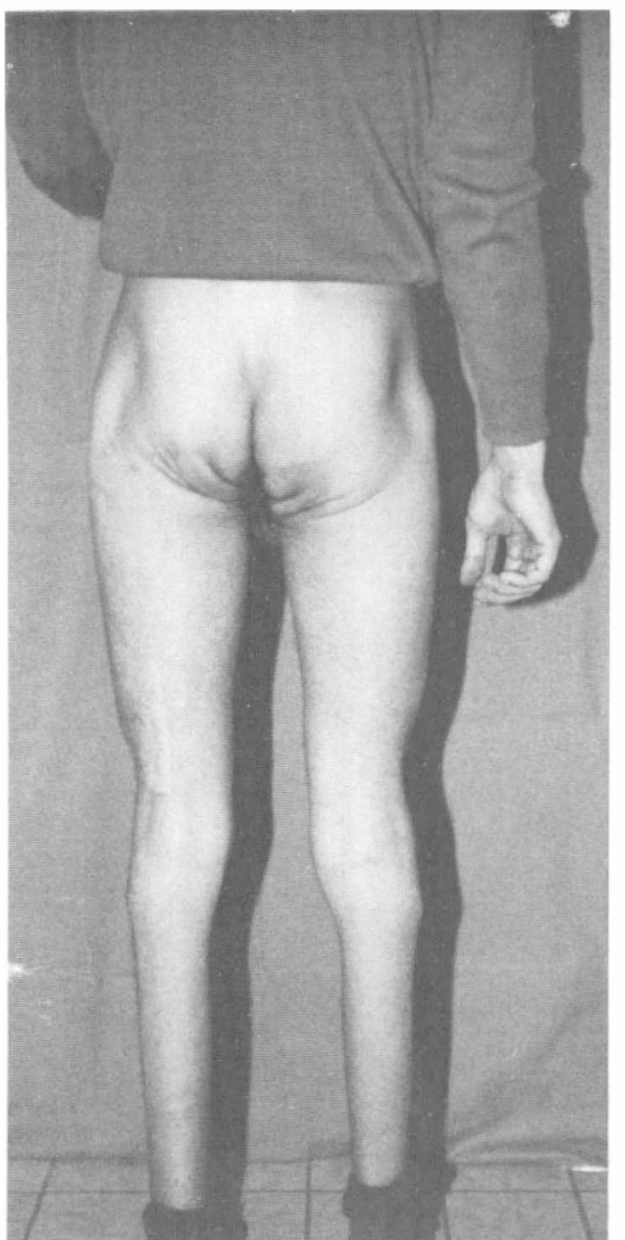

FIG. 3

After 8 months seen from behind. The patient has already readjusted: he feels touch and pin-pricks in the ischial region and no longer in the above knee region. Bowel control has improved.

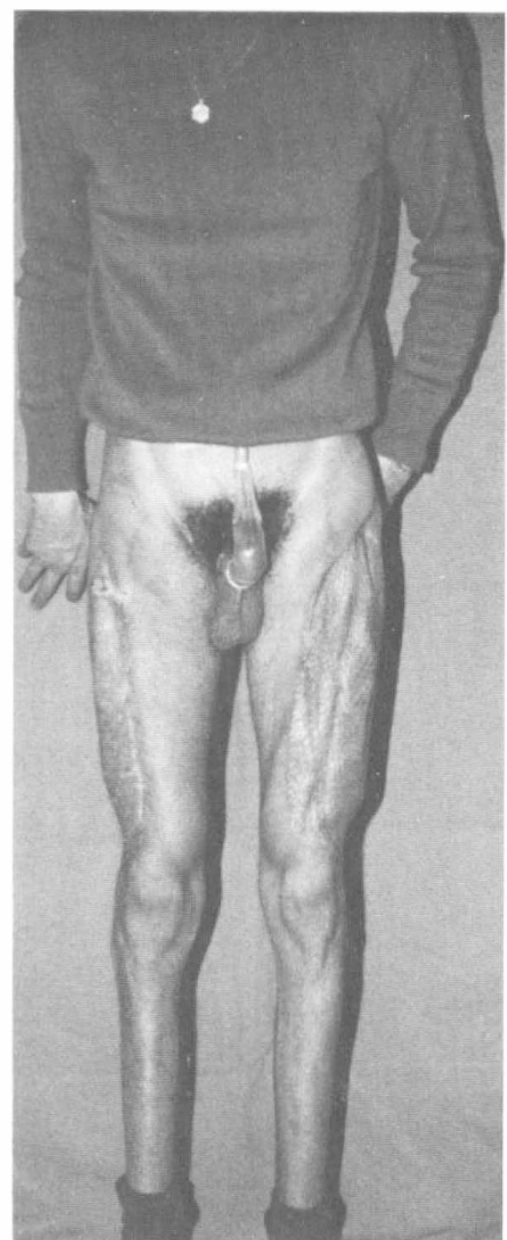

FIG. 4

The frontal view after 8 months shows the healing scars.

\section{Discussion}

If properly selected, muscle and/or musculocutaneous and sensory innervated TFL-flaps are very rewarding procedures especially when the flap helps to render formerly anaesthetic regions into sensitive areas and by this way helping to resocialise and to reintegrate the patient in the working process by allowing him to sit. 
Acknowledgement: We would like to express our deepest gratitude to Professor Serge Krupp for his invaluable help.

\section{RÉSUMÉ}

Chez les patients atteints d'une affection de la moelle épinière, soit-elle d'origine traumatique ou maladive, les ulcères de décubitus récidivants ou les cicatrices instables peuvent être guéris au moyen de lambeaux musculaires ou musculocutanés, car ceux-ci offrent un traitement de choix: ils assurent à la fois un rembourrage et de la peau intacte.

La mise en place d'un lambeau sensible du tenseur du fascia lata ou le transfert libre d'un lambeau cutané, au moyen des techniques micro-chirurgicales, vasculaires et nerveuses garantit une protection contre les lésions par pression dans les zônes d'appui du bassin. Cette méthode aide définitivement à la réhabilitation du patient.

\section{ZUSAMMENFASSUNG}

Bei Versagen der üblicherweise strikt konservativen Behandlung von Decubitalulcera und instabilen Narben benützen wir bei Rezidiven seit 197 I Transpositions-Rotationsmuskellappenplastiken und/oder Muskel-Haut-Lappen-Plastiken. Auf diese Weise gelingt es uns die kritschen Stellen mit entsprechender Polsterung zu versehen. Mit solchen Lappen sehen wir bessere Resultate als mit üblichen reinen Hautlappen.

Seit anfangs 1980 haben wir die sensiblen Tensor Fasciae Latae Muskel-Haut-Lappen in Gebrauch. Diese Lappen geben Patienten mit einer Paraplegie unterhalb $\mathrm{L}_{3}$ nicht nur Schutz und Polsterung der Trochanter- und/oder Sitzbeingegend sondern vermitteln überdies ein neues Körpergefühl in einer ehedem asensiblen Gegend. Idealerweise kann diese neuartige Lappen-technik auch bei Patienten angewendet werden, die an Lähmungen infolge einer Meningom; elocele leiden.

Präoperative Tests, Indikationen, prä- und postoperative Behandlung, anatomische Gegebenheiten, Techniken und die Resultate werden diskutiert.

\section{REFERENCES}

Bostwick, III. J., Hill, H. L. \& NaHAI, F. (1979). Repairs in the lower abdomen, groin, or perineum with myocutaneous or omental flaps. Plast. reconstr. surg., 63, I86-194.

Campbell, R. M. \& Delgado, J. P. (1977). The pressure sore. Chp. 9I, pp. 3763-3799. in Reconstructive Plastic Surgery. ed. by J. M. Converse. W. B. Saunders Co., Philadelphia. 2nd ed.

Cannon, B., Constable, J. D., Furlow, L. T., Hayhurst, J. W., McCarthy, J. G. \& MCCRAW, J. B. (I977). Reconstructive surgery of the lower extremity. Chp. 86, pp. 352 I-3566 in Reconstructive Plastic Surgery. ed. by J. M. Converse. W. B. Saunders Co., Philadelphia. 2nd ed.

Conway, H. \& GRIfFith, B. H. (I956). Plastic surgery for closure of decubitus ulcers in patients with paraplegia, based on experience with 1000 cases. Amer. F. Surg., 91, 946-975.

Daniel, R. K. \& Williams, H. B. (1973). The free transfer of skin flaps by microvascular anastomosis. Plast. reconstr. surg., 52, I6-3 I.

Dansereau, R. K. \& Conway, H. (1964). Closure of decubiti in paraplegics. Report of 2000 cases. Plast. reconstr. surg., 33, 474-480.

Dibell, D. G. (1974). Use of a long island flap to bring sensation to the sacral area in young paraplegics. Plast. reconstr. surg., 54, 220-223.

Dibell, D. G., McCraw, J. B. \& Edstrom, L. E. (I979). Providing useful and protective sensibility to sitting area in patients with meningomyelocele. Plast. reconstr. surg., 64, 796-799.

Ger, R. \& Levine, S. A. (1976). The management of decubitus ulcers by muscle transposition. An 8 year review. Plast. reconstr. surg., 58, 419-428.

GutTmanN, Sir L. (1955). Problems of treatment of pressure sores in spinal paraplegics. Brit. F. Plast. Surg., 8, 196-213.

Hill, H., Hester, R. \& Nahai, F. (1979). Covering of large groin defects with the tensor fascia lata musculocutaneous flap. Br. F. Plast. Surg., 32, I2-I4. 
KRUPP, S. (1972). The operative treatment of pressure sores in paraplegics. Reconstr. Surg. Traumat., 13, 159-182.

KRUPP, S. \& ZAECH, G. A. (I976). Operative treatment of pressure sores in paraplegics by rotation flap. Paraplegia, 14, 29-35.

KRUPP, S., SeILeR, W. \& ZaECH, G. A. (1979). Behandlung von Druckulzera und unstabilen Narben im Bereiche des Beckens und der unteren Extremität. Méd. et Hyg., 37, 810-814.

Krupp, S., KuHN, W. \& ZaECH, G. A. (I98I). Progrès récents dans le traitement chirurgical des ulcères de décubitus. Méd. et Hyg., 39, 754-758.

KRUPP, S. \& ZAECH, G. A. (I98I). Zur Behandlung von Druckulzera bei Paraplegikern. Schweiz. Rundschau. Med. (PRAXIS), 70, Nr. 28, I28I-I284.

Krupp, S., KuhN, W. \& ZAECH, G. A. (I982). Le Lambeau sensible du tenseur du fascia lata. Helv. chir. Acta, 49, 2 I 7-2 I 8.

Mathes, S. J., Vasconez, L. O. \& JuRkiewicz, M. J. (I977). Extensions and further applications of muscle flap transposition. Plast. reconstr. surg., 60, 6-I 3 .

MATHES, S. J. \& BuChANAN, R. (I979). Tensor fascia lata: neurosensory musculo-cutaneous free flap. Brit. F. Plast. Surg., 32, I84-187.

McCraw, J. B., Massey, F. M., Shankin, K. D. \& Horton, C. E. (1976). Vaginal reconstruction with gracilis myocutaneous flaps. Plast. reconstr. surg., 58, I76-I83.

McCraw, J. B., Dibell, D. G. \& Carraway, J. H. (1977). Clinical definition of independent myocutaneous vascular territories. Plast. reconstr. surg., 60, $34 \mathrm{I}-352$.

McCraw, J. B. \& Dibell, D. G. (1977). Experimental definition of independent myocutaneous vascular territories. Plast. reconstr. surg., 60, 2 I 2-220.

McGregor, J. C. \& Buchan, A. C. (I980). The tensor fasciae latae flap and its use in the closure of trochanteric and ischial pressure sores. Paraplegia, 18, 30I-305.

Nahai, F., Hill, H. L. \& Hester, T. R. (I979). Experiences with the tensor fascia lata flap. Plast. reconstr. surg., 63, 788-799.

Orticochea, M. (1972). A new method of total reconstruction of the penis. Brit. $\mathcal{F}$. Plast. Surg., 25, 347-366.

Pers, M. \& Medgyesi, S. (I973). Pedicle muscle flaps and their applications in the surgery of repair. Brit. F. Plast. Surg., 26, 31 3-32 I.

Shand, E. G. \& McClemont, E. (1979). Recent advances in the treatment of pressure sores. Paraplegia, 17, 400-406.

Souyris, F., Gary-Bobo, A., REynaud, J. P. \& Charissoux, G. (I980). Lambeau myocutané du tenseur du fascia lata. Mises au point anatomiques et téchniques. Ann. Chir. Plast., 25, 2, I 59-162.

Vasconez, L. O. \& McCraw, J. B. (I980). Symposium on myocutaneous flaps. Clinics in Plastic Surgery Vol. 7. 